\title{
Ex Vivo Analysis of Cytotoxic T Lymphocytes to Measles Antigens during Infection and after Vaccination in Gambian Children
}

\author{
Assan Jaye, Albert F. Magnusen, Abubakar D. Sadiq, Tumani Corrah, and Hilton C. Whittle \\ Medical Research Council Laboratories, Banjul, The Gambia
}

\begin{abstract}
The study of cytotoxic $\mathrm{T}$ cell responses to measles antigens during infection and after vaccination may provide insight into the immunopathology of the infection. It will also provide a knowledge of the immunity conferred by wild or attenuated virus, which will help in the design of new vaccines. Direct cytotoxic $T$ cell responses, which did not require in vitro restimulation, were measured from peripheral blood by a standard ${ }^{51} \mathrm{Cr}$-release assay in 35 patients with acute measles, using HLA class I matched allogeneic B cells as targets. $77 \%$ showed specific responses to measles fusion protein, $69 \%$ to the hemagglutinin, and $50 \%$ to the nucleoprotein. These responses, which were related to severity of disease and history of previous vaccination, had waned by 14-24 wk after measles when memory responses to the same antigens could be elicited by restimulation in $71 \%$ of the 13 patients tested. A similar pattern followed vaccination: direct cytotoxic responses to fusion and hemagglutinin proteins were shown in $70 \%$ of the 20 children tested while $50 \%$ responded to the nucleoprotein. These responses, which were mediated by both $\mathrm{CD}^{+}$and $\mathrm{CD}^{+}$ cells, faded over 6 wk when memory responses could be restimulated. Thus, a vigorous cytotoxic $\mathrm{T}$ lymphocyte response to fusion, hemagglutinin, and nucleoproteins is important in both natural and vaccine-induced immunity to measles. (J. Clin. Invest. 1998. 102:1969-1977.) Key words: viral infection - peripheral blood mononuclear cells $\bullet$ memory $\mathrm{T}$ cells $\bullet$ direct lysis $\cdot \mathrm{CD}^{+} / \mathrm{CD}^{+}$cells
\end{abstract}

\section{Introduction}

Measles continues to be a major public health problem in developing countries despite high global vaccine coverage by the Expanded Program on Immunization (1). The limitations of the live vaccine coupled with inadequate coverage in developing countries allow about a million children to die of measles every year $(2,3)$, thus making measles responsible for more deaths than any of the other targeted diseases in the Expanded Program on Immunization. The reconstituted live attenuated vaccine is not fully heat stable and induces low seroconversion

Address correspondence to Dr. Assan Jaye, Medical Research Council Laboratories, P.O. Box 273, Banjul, Fajara, The Gambia, West Africa. Phone: 220-495442/6; FAX: 220-496513 or 495919; E-mail: ajaye@mrc.enda.sn

Received for publication 5 March 1998 and accepted in revised form 28 September 1998.

J. Clin. Invest.

(C) The American Society for Clinical Investigation, Inc. 0021-9738/98/12/1969/09 \$2.00

Volume 102, Number 11, December 1998, 1969-1977

http://www.jci.org rates in the presence of maternal antibodies (4). In practice, as the level and decay of maternal antibodies are variable and unpredictable, it has been difficult to determine an optimal age of vaccination in infancy which balances protection against the likelihood of vaccine failure. Thus, to achieve global eradication of measles there is a need to develop alternative vaccines that can be given to young infants which are not only unaffected by maternal antibody, but are capable of inducing longlasting and appropriate antibody and cytotoxic T lymphocyte $(\mathrm{CTL})^{1}$ responses.

Measles induces both humoral and cell-mediated immune responses and the importance of the cellular immune response in the control and elimination of infection has long been recognized from early studies of immunodeficient children. Agammaglobulinemic patients who produced no detectable virus-specific antibodies showed normal clinical symptoms and developed resistance to reinfection after contracting measles, whereas children with functional $\mathrm{T}$ cell deficiencies often suffered fatal giant cell pneumonia $(5,6)$. Some progress has then been made in documenting the biological significance and cellular characteristics of cell-mediated immune responses to measles in developed countries (7-10). However, this has not been matched by a detailed understanding of the CTL responses to specific components of the measles virus. Furthermore, there is a dearth of information on CTL responses after natural measles or vaccination in developing regions such as West Africa where measles is highly endemic and children are infected or vaccinated at a much earlier age than in the Western World. Mortality rates are high, especially in the young (11) and vaccine failure, associated with milder disease, is common (12).

The approach to the evaluation of the role of structural proteins in the induction of protective immunity in measles has obvious implications for the rational design of new generations of vaccine and is being actively pursued in murine models (1318). Although information is beginning to emerge from studies in humans (19-21), an extension of the research on immune responses to measles gene products during the disease in genetically different human populations in endemic areas will provide information for the development of new vaccines and for understanding the pathogenesis of the infection and the basis of vaccine failure.

Recently, we described a new method of stimulating CTL responses to measles antigens in immune adults of both Caucasian and African origin (22). In a continuation of these studies, we present details of CTL responses to different measles proteins during and after measles during two outbreaks in The Gambia in the dry seasons of 1995/96 and 1996/97. CTL responses were also determined in healthy children who were vaccinated with live measles at 9 mo of age. Fresh or direct re-

1. Abbreviations used in this paper: $\mathrm{CTL}$, cytotoxic $\mathrm{T}$ lymphocyte; $\mathrm{F}$, fusion; H, hemagglutinin; MRC, Medical Research Council; N, nucleoprotein. 
sponses directed to fusion $(\mathrm{F})$ and hemagglutinin $(\mathrm{H})$ proteins of measles were found during acute infection in many of the patients and after vaccination. Measles-specific CTL could be restimulated $14 \mathrm{wk}$ after infection and after vaccination.

\section{Methods}

Patients. Two successive outbreaks of measles occurred in the greater Banjul area of The Gambia during the dry seasons of 1995/96 and 1996/97. 835 cases of measles were seen at the Medical Research Council (MRC) outpatient clinic and some of these patients aged 5 mo to $25 \mathrm{yr}$ were recruited in the study. The clinical diagnosis and categorization of cases into mild, moderate, and severe were in accordance with prescribed criteria (23) and the history of vaccination was obtained from clinic record cards. PBMC were isolated by density gradient centrifugation and portions of the cells were used for HLA class I typing by standard serological microcytotoxicity methods (24). The remainder was used for CTL assays. In the direct CTL assays, which use fresh cells, constraints with regard to time and cell numbers did not allow us to type class II alleles which required time-consuming molecular methods (25).

Vaccinated infants. Newly born babies were recruited at a local maternity center close to the MRC hospital. Cord blood was obtained at birth, PBMC were separated, and autologous B cells were generated after EBV transformation (26). 9 mo later, the infants were vaccinated against measles at a government health center and bled 2-12 wk after vaccination to measure CTL activity. Three of them were rebled 24-31 wk after vaccination for a repeat assay. Batches of vaccines from the center were checked for potency and all were found to be satisfactory. Informed consent was obtained from all subjects, their parents, or guardians. The Gambia Government/MRC ethical committee granted ethical approval for both studies.

Reagents. RPMI 1640 and DMEM were obtained from Sigma Chemical Co. (St. Louis, MO). FBS and tryptose phosphate broth were supplied by GIBCO BRL (Life Technologies, Paisley, UK). The IL-2 (lymphocult-T) was purchased from Biotest (Dreieich, Germany). The 24-well culture plates were from Costar Corp. (Cambridge, MA). The sodium $\left[{ }^{51} \mathrm{Cr}\right]$ chromate was obtained from Amersham (Buckinghamshire, UK) and the immunomagnetic beads (M-450 Dynabeads) were the product of DYNAL (Oslo, Norway).

Measles virus and vaccinia recombinants. Measles virus low passage Edmonston strain was used in our stimulation protocol; the source and propagation of this virus have been described previously (22). In brief, the virus was cultured and titrated on Vero cells in RPMI 1640 medium supplemented with $10 \%$ (vol/vol) FCS, $2 \mathrm{mM}$ L-glutamine, penicillin $(100 \mathrm{U} / \mathrm{ml})$, streptomycin $(100 \mu \mathrm{g} / \mathrm{ml})$ (referred to as R-10 medium), and kept in aliquots at $-70^{\circ} \mathrm{C}$. Dr. Fabian Wild (Institute Pasteur De Lyon) kindly provided the vaccinia virus constructs expressing F protein, $\mathrm{H}$ protein, and nucleoprotein $(\mathrm{N})$. These viruses were propagated on baby hamster kidney cells in DMEM supplemented with $10 \%$ FCS, $10 \%$ tryptose phosphate broth, $2 \mathrm{mM}$ L-glutamine, penicillin $(100 \mathrm{U} / \mathrm{ml})$, streptomycin $(100 \mu \mathrm{g} / \mathrm{ml})$, and titrated on Vero cells as for the measles virus. Expression of the recombinants was confirmed by indirect immunofluorescence assay after infection of B cells and Vero cells using measles protein-specific monoclonal antibodies (courtesy of Dr. Wild, WHO Reference Center, Lyon, France). Vaccinia constructs, vSC8 expressing $\beta$-galactosidase, and NP27 expressing influenza N proteins obtained from the Molecular Immunology Group (Institute of Molecular Medicine, Oxford, UK) were used as control recombinants.

Preparation of PBMC as fresh effectors and stimulation of CTL. PBMC isolated from patients with measles were prepared for direct assay by adding $10 \%$ IL-2 to R-10 and culturing these cells in a $24-$ well plate at $2 \times 10^{6} /$ well at $37^{\circ} \mathrm{C}$ in a $5 \% \mathrm{CO}_{2}$ humidified incubator for $2 \mathrm{~d}$. Meanwhile, after HLA serotyping, allogeneic B cell lines that were partially matched at one or more class I loci were selected as targets from our library of cell lines. Either of two B cell lines (T7526:
A2*07, B46, C11, DR9, DQ3 or BM16: A2*07, B18, C7, DR12, DQ3, DP2) which contain HLA class I and class II haplotypes rarely seen in The Gambia was used for complete mismatching experiments. To stimulate CTL from PBMC of patients at follow-up and of vaccinated donors we used the strategy of inducing CTL in vitro with Edmonston measles virus as described in the study in immune adults (22). In brief, $10 \%$ of the PBMC were infected with the measles virus at an moi of 1 for $16 \mathrm{~h}$ at $37^{\circ} \mathrm{C}$. The cells were washed and exposed to ultraviolet light for $2.5 \mathrm{~min}$, washed once more, and returned to the PBMC in culture. The stimulated PBMC were grown in R-10 in 24-well plates for 10-12 $\mathrm{d}$ with the addition of IL-2 at day 7 before a standard cytotoxicity assay was performed using the same targets as in the direct CTL assay.

CTL assay and cell separation by immunomagnetic beads. Cytolytic activity was measured in a standard ${ }^{51} \mathrm{Cr}$-release assay at an $\mathrm{E} / \mathrm{T}$ ratio of 20 viable effector cells: 1 viable target cell as described previously (22). The target cells were prepared by infecting autologous EBVtransformed B cells or allogeneic HLA matched or mismatched cells with vaccinia recombinants expressing measles proteins or $\beta$-galactosidase at an moi of 5 for $16 \mathrm{~h}$ at $37^{\circ} \mathrm{C}$ before conducting a standard 4-h ${ }^{51} \mathrm{Cr}$-release assay. Percentage lysis to control vaccinia was subtracted from that to the measles antigen to give a value for measlesspecific lysis. If this was $\geq 10 \%$ it was regarded as significant. Immunomagnetic bead selection was carried out with M-450 Dynabeads and these cells were then used in the ${ }^{51} \mathrm{Cr}$-release assay. The Dynabeads reliably depleted $80-90 \%$ of $\mathrm{CD}^{+}$or $\mathrm{CD} 8^{+}$cells, respectively (22).

\section{Results}

Fresh or unstimulated CTL in the acute phase of measles infection

With the use of allogeneic EBV-transformed B cells matched at one or two class I loci in a direct CTL assay, $77 \%$ of acutely infected patients showed a specific CTL response directed to the $\mathrm{F}$ protein and $69 \%$ of them to the $\mathrm{H}$ protein with mean maximal lysis $( \pm \mathrm{SD})$ of $16.7 \pm 6.1 \%$ and $20.0 \pm 11.1 \%$, respectively, at an E/T ratio of 20:1 (Table I). CTL response to the $\mathrm{N}$ protein was shown in $50 \%$ of patients with mean lysis of $15.6 \pm 6.0 \%$.

CTL lysis to the F protein was weakly but significantly correlated with age and the time elapsed between sampling and the onset of the rash $(r=0.34, n=35, P<0.05 ; r=0.42, n=$ $35, P<0.01$, respectively). Correlations between CTL to $\mathrm{H}$ and $\mathrm{N}$ proteins were not significant. The 11 failed vaccinees showed direct CTL to one or more measles polypeptides at a similar frequency and with a mean specific lysis that did not differ significantly from those who had not been vaccinated (Table I). There was a correlation between severity of disease and CTL responses: 3 of 6 patients with severe measles failed to show any significant cytolysis to the $\mathrm{F}, \mathrm{H}$, and $\mathrm{N}$ proteins as compared with 1 out of 26 with moderate or mild disease $(P=$ 0.015 , two-tailed Fisher's exact test). The mean cytolytic values were $6.5 \pm 5.7,6.5 \pm 5.9$, and $3.3 \pm 3.7 \%$ for the $\mathrm{F}, \mathrm{H}$, and $\mathrm{N}$ proteins, respectively; the corresponding values for patients with mild or moderate measles were $15.1 \pm 7.9,16.7 \pm 12.9$, and $11.5 \pm 7.2 \%$, respectively $(P<0.02$ for $\mathrm{F}$ and $\mathrm{N}$ and $P=0.069$ for $\mathrm{H}, t$ test).

\section{HLA class I restriction of direct CTL}

Table I shows that $56 \%$ of the subjects recognized two or three of the polypeptide antigens at the same time when class I matched targets were used; 5 out of these 19 patients (M37, M78, M80, M91, and M74) were matched at the B53 allele. 
Table I. Direct CTL-mediated Cytotoxicity in Patients with Measles

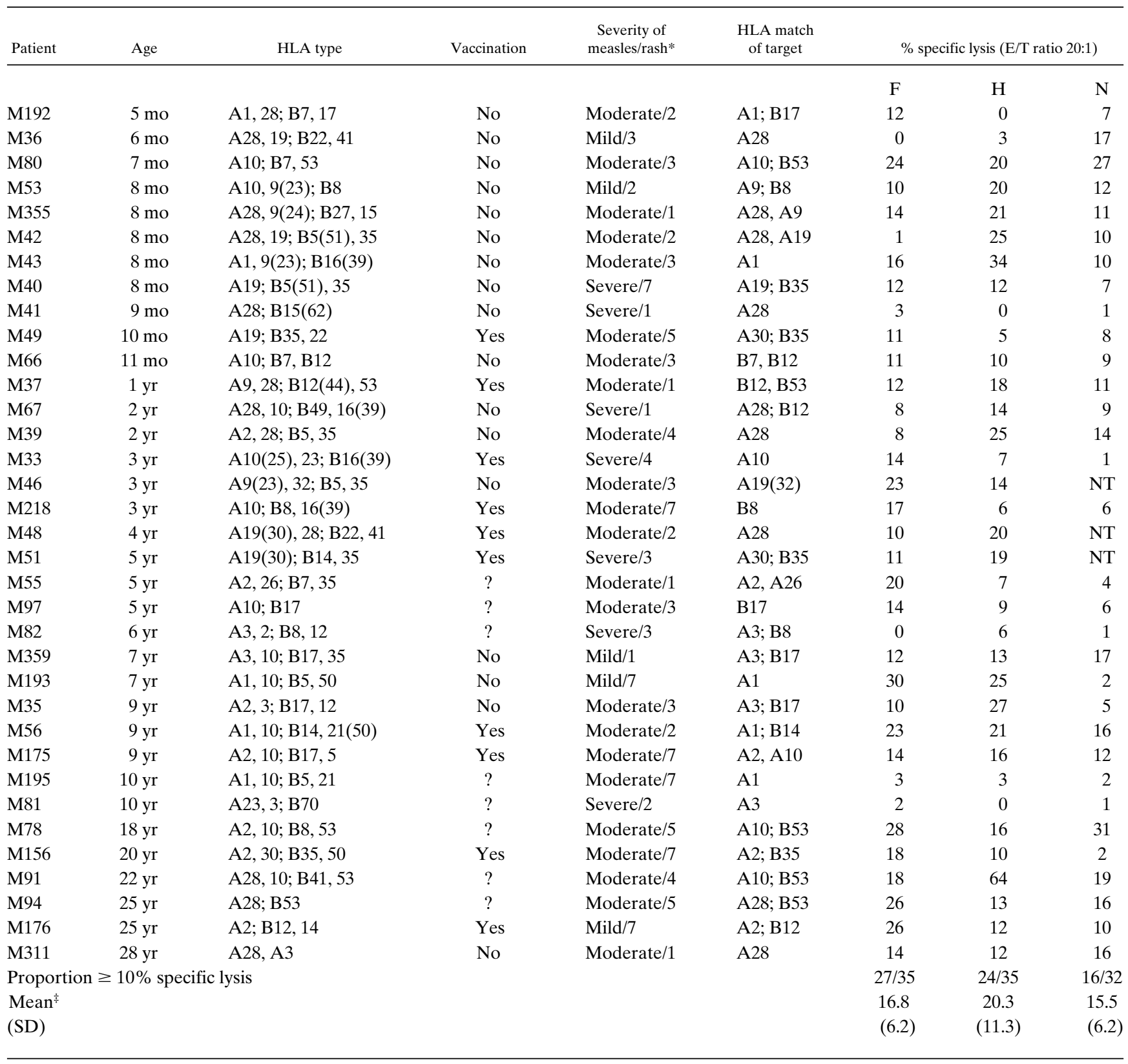

*Days after onset of rash in relation to time of sampling. ${ }^{\ddagger}$ Patients with specific lysis $\geq 10 \%$. NT, not tested.

The other commonly matched class I alleles that appeared to restrict killing were A1 (M43, M56, and M193), A2 (M55, M175, M176, and M156), B12 (M37, M66, M67, and M176), and A28 (M48, M94, M192, M311, and M355) which also showed killing against $\mathrm{N}$ protein in three patients (M36, M39, and M42). A repeat assay of M192 using a different target matched against A28 increased lysis in all three proteins to 18, 27 , and $18 \%$ for the $\mathrm{F}, \mathrm{H}$, and $\mathrm{N}$ proteins, respectively, suggesting a role for multiple epitope restriction by the A28 allele. However, as we were not able to determine the HLA class II identity of our patients, these results must be interpreted with caution for lysis may have also been due to fortuitous matching at class II loci.

In seven patients (M46, M55, M66, M67, M80, M91, and M94), class I matched and a class I and class II mismatched tar- get (T7526 or Bm16) were used. The average lysis against the $\mathrm{F}$ and $\mathrm{H}$ proteins with matched targets was 19 and $20 \%$, respectively, whereas against mismatched cells it fell to 3 and $2 \%$, respectively (data not shown), thus confirming that the cytotoxic responses were HLA restricted. There were sufficient cells from eight patients to test CTL at ratios of 20:1 and 10:1. Mean lysis for the $\mathrm{F}$ protein at the higher ratio was $16.3 \pm 3.2 \%$ and at the lower ratio $11.0 \pm 1.1 \%$. The respective values for the $\mathrm{H}$ protein were $25.2 \pm 6.3$ and $16.6 \pm 2.3 \%$.

\section{Direct CTL is mediated by $C D 8^{+}$and $C D 4^{+}$cells}

Cell separation experiments demonstrated that both $\mathrm{CD} 8^{+}$ and $\mathrm{CD}^{+}{ }^{+}$-depleted cells from patient M311 showed measlesspecific killing of a target of known class I match (A28) (Fig. 1 $A)$. Subsequent retyping of preserved cells from this patient 

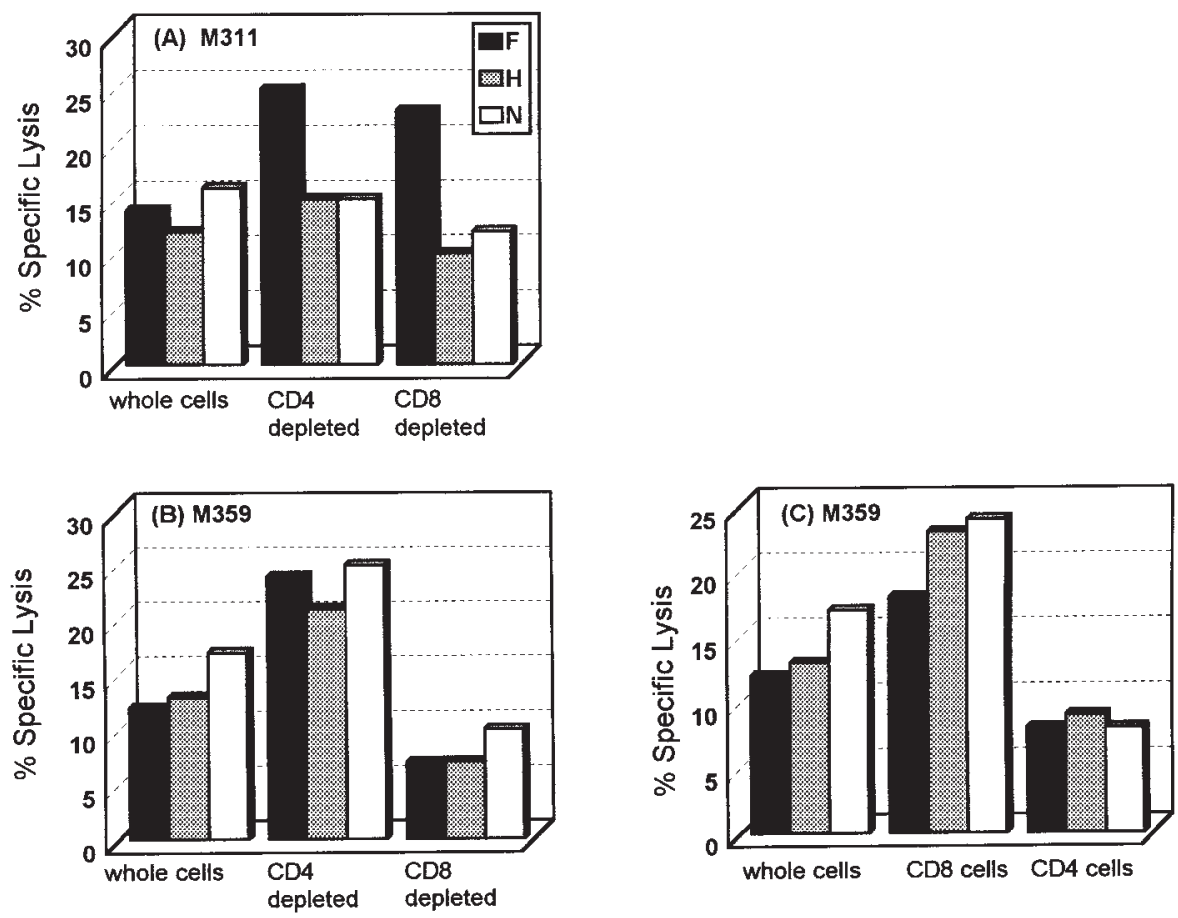

Figure 1. Phenotypic analysis of direct CTL in acute measles. PBMC from patients M311: HLA A3, A28 $(A)$ and M359: HLA A3, 10; B17, 35 (B) were subjected to two rounds of depletion with immunomagnetic beads. Depleted subpopulations as well as whole cells were tested against allogeneic B cells matched at the A28 allele and at A3, B17 alleles, respectively, in a direct CTL assay at an E/T ratio of 20:1. After depletion, cells from M359 were detached from beads and tested against targets at an $\mathrm{E} / \mathrm{T}$ ratio of $12: 1$ for $\mathrm{CD}^{+}$ cells and 20:1 for $\mathrm{CD}^{+}$cells, respectively $(C)$. The HLA class II match of the target for M311 was at DQB5 but was unknown for M359.

and of the target cells by a molecular based method (25) also revealed matching at class II DQB5 allele. $\mathrm{CD} 4^{+}$-depleted cells from another donor (M359) mediated specific killing of $\mathrm{A} 3$ and $\mathrm{B} 17$ matched targets $\left(\right.$ Fig. $1 \mathrm{~B}$ ). In addition, $\mathrm{CD}^{+}$cells from this donor when detached from the beads and used at ratio 12:1 gave high CTL values whereas detached $\mathrm{CD}^{+}$cells showed little killing (Fig. $1 \mathrm{C}$ ). However, cells were unavail- able from this patient for class II typing. In another experiment detached $\mathrm{CD}^{+}$cells from a different donor (M355) gave similar results (data not shown). Thus, our results suggest that both $\mathrm{CD}^{+}$and $\mathrm{CD}^{+}$cells can be involved in direct cytotoxicity but, due to difficulties in HLA class II matching, the relative roles of the two phenotypes in killing were not clearly defined.

Table II. Direct and Stimulated CTL Responses in Patients after Recovery from Measles

\begin{tabular}{|c|c|c|c|c|c|c|c|c|c|}
\hline \multirow[b]{2}{*}{ Patients } & \multirow{2}{*}{$\begin{array}{c}\text { Time after } \\
\text { measles }\end{array}$} & \multirow{2}{*}{$\begin{array}{l}\text { Direct CTL } \\
\text { response } \\
\text { in acute phase* }\end{array}$} & \multirow{2}{*}{$\begin{array}{l}\text { HLA match } \\
\text { of target }^{\ddagger}\end{array}$} & \multicolumn{6}{|c|}{$\%$ specific lysis (E/T ratio 20:1) } \\
\hline & & & & & Direct & & & Stimulated & \\
\hline \multicolumn{10}{|c|}{$w k$} \\
\hline & & & & $\mathrm{F}$ & $\mathrm{H}$ & $\mathrm{N}$ & $\mathrm{F}$ & $\mathrm{H}$ & $\mathrm{N}$ \\
\hline M82 & 9 & - & A3;B8 & 13 & 15 & 17 & 42 & 22 & 23 \\
\hline M67 & 10 & - & A28;B12 & 0 & 0 & 0 & 3 & 2 & 3 \\
\hline M56 & 12 & + & A1;B14 & 11 & 10 & 9 & 17 & 34 & 29 \\
\hline M51 & 14 & + & A30;B35 & 10 & 0 & 1 & 48 & 17 & 0 \\
\hline M80 & 14 & + & A10;B53 & 5 & 20 & 21 & NT & NT & NT \\
\hline M41 & 16 & - & A28 & 7 & 2 & 2 & 0 & 0 & 0 \\
\hline M43 & 16 & + & A1 & 3 & 0 & 8 & 17 & 20 & 10 \\
\hline M36 & 16 & + & A28 & 0 & 2 & 1 & 2 & 0 & 3 \\
\hline M53 & 17 & + & A9;B8 & 3 & 4 & 4 & 21 & 18 & 38 \\
\hline M78 & 17 & + & A10;B53 & 2 & 3 & 2 & 24 & 17 & 24 \\
\hline M37 & 18 & + & B12,B53 & 10 & 4 & 0 & 51 & 50 & 24 \\
\hline M42 & 20 & + & A28,A19 & 9 & 4 & 13 & 6 & 31 & 12 \\
\hline M35 & 24 & + & A3;B17 & 4 & 11 & 7 & 18 & 27 & 2 \\
\hline M39 & 24 & + & A28 & 7 & 3 & 5 & 10 & 29 & 11 \\
\hline \multicolumn{4}{|c|}{ Proportion $\geq 10 \%$ specific lysis } & $4 / 14$ & $4 / 14$ & $3 / 14$ & $9 / 13$ & $10 / 13$ & $8 / 13$ \\
\hline \multirow{2}{*}{\multicolumn{4}{|c|}{$\begin{array}{l}\text { Mean }^{\S} \\
\text { (SD) }\end{array}$}} & & & & 27.5 & 26.5 & 21.3 \\
\hline & & & & & & & $(15.2)$ & $(10.2)$ & $(9.8)$ \\
\hline
\end{tabular}

*See Table I for data. ${ }^{*}$ The same allogeneic matched cell lines used as in Table I. ${ }^{\S}$ Patients with specific lysis $\geq 10 \%$. NT, not tested. 
Stimulated CTL during measles and after recovery

We tried to stimulate CTL in the acute phase of infection in 10 patients but were unsuccessful since the stimulation procedure activated preinfected cells to release virus which in turn infected the effector cells, resulting in a progressive increase in giant cells which are a marker of measles infection. However, in the recovery period, we were able to test 14 patients between 9 and 24 wk after measles both by direct assay and after stimulation. Table II shows that direct CTL responses could only be found during this period in three individuals; however, the majority of CTL responses were observed after in vitro restimulation. An unexpected observation was the strong response in both direct and stimulated assays of M82 who had no CTL in the acute phase. We failed to stimulate the response to $\mathrm{N}$ in M36 who responded to this protein in the acute phase.

\section{Measles-specific CTL responses after vaccination of} healthy infants

Direct killing. Direct measles-specific CTL responses of 22 healthy infants 2-6 wk after measles vaccination are shown in Table III. Autologous B cells derived from cord blood at birth were used as antigen-presenting cells. $70 \%$ of those tested in the direct assay responded to the $\mathrm{F}$ and $\mathrm{H}$ antigens, respectively, and $50 \%$ responded to the $\mathrm{N}$ antigens with maximal mean lysis $( \pm$ SD) of $22 \pm 9,15 \pm 7$, and $13 \pm 3 \%$, respectively, at an $\mathrm{E} / \mathrm{T}$ ratio of 20:1. As a control for specificity, we also tested five of the subjects using additional targets infected with vaccinia expressing influenza $\mathrm{N}$ protein. None of the vaccinated infants, who were most unlikely to have been exposed to influenza, tested positive against this protein (data not shown).

Restimulation. Restimulation of CTL was also undertaken when sufficient PBMC were available from our donors. In general, restimulation gave lower cytolysis in the first 3-4 wk than direct assays; thereafter restimulation was more successful. Three subjects, in whom marginal responses were observed in the direct assay (CBL2, CBL3, and CBL39), failed to show responses after restimulation. The exception was CBL46 who was tested later at $12 \mathrm{wk}$ and showed no direct response but some killing after restimulation. Three subjects (CBL121, CBL134, and CBL146) who had shown direct cytotoxicity 4-6 wk after vaccination were retested at 24,31 , and $31 \mathrm{wk}$, respectively, at an E/T ratio of 20:1. Now no direct cytotoxicity could be shown (Fig. $2 A$ ) but restimulation gave marked lysis averaging 20,17 , and $14 \%$ for targets expressing the F, H, or N protein, respectively (Fig. $2 \mathrm{~B}$ ).

Reproducibility and cells involved in direct cytolysis. The reproducibility of the direct assay was tested at three E/T ratios using cells from subject CBL154. Cytolysis was reproducible and fell as the E/T ratio declined (data not shown). Fresh effector cells obtained $4 \mathrm{wk}$ after vaccination were twice depleted of $\mathrm{CD}^{+}$and $\mathrm{CD}^{+}$cells using immunomagnetic beads. These experiments demonstrated that the CTL responses in

Table III. Direct and Stimulated CTL Responses to Measles Antigens after Immunization of Children at 9 mo of Age

\begin{tabular}{|c|c|c|c|c|c|c|c|}
\hline \multirow[b]{2}{*}{ Donor } & \multirow{2}{*}{$\begin{array}{l}\text { Period after } \\
\text { vaccination }\end{array}$} & \multicolumn{6}{|c|}{$\%$ specific lysis (E/T ratio $20: 1$ ) } \\
\hline & & \multicolumn{3}{|c|}{ Direct } & \multicolumn{3}{|c|}{ Stimulated } \\
\hline \multicolumn{8}{|c|}{$w k$} \\
\hline & & $\mathrm{F}$ & $\mathrm{H}$ & $\mathrm{N}$ & $\mathrm{F}$ & $\mathrm{H}$ & $\mathrm{N}$ \\
\hline CBL11 & 2 & 13 & 3 & 6 & 7 & 8 & 3 \\
\hline CBL39 & 2 & 10 & 10 & 12 & 0 & 0 & 8 \\
\hline CBL55 & 2 & 24 & 11 & 15 & & NT & \\
\hline CBL92 & 2 & 37 & 26 & 11 & 11 & 18 & 10 \\
\hline CBL101 & 2 & 4 & 12 & 11 & 7 & 12 & 1 \\
\hline CBL20 & 3 & 30 & 20 & 12 & & NT & \\
\hline CBL56 & 3 & 5 & 8 & 6 & & NT & \\
\hline CBL2 & 4 & 9 & 10 & 2 & 9 & 2 & 3 \\
\hline CBL3 & 4 & 11 & 11 & 7 & 1 & 3 & 0 \\
\hline CBL9 & 4 & 36 & 33 & 16 & 12 & 17 & 10 \\
\hline CBL38 & 4 & 0 & 9 & 0 & & NT & \\
\hline CBL134 & 4 & 19 & 10 & 12 & & NT & \\
\hline CBL146 & 4 & 18 & 14 & 8 & & NT & \\
\hline CBL30 & 5 & & NT & & 11 & 22 & 11 \\
\hline CBL32 & 5 & & NT & & 9 & 12 & 12 \\
\hline CBL8/2 & 6 & 31 & 18 & 21 & 15 & 19 & 24 \\
\hline CBL49 & 6 & 15 & 16 & 12 & & NT & \\
\hline CBL74 & 6 & 19 & 3 & 7 & 0 & 12 & 2 \\
\hline CBL6 & 6 & 28 & 10 & 13 & 29 & 13 & 12 \\
\hline CBL96 & 6 & 0 & 2 & 2 & & NT & \\
\hline CBL121 & 6 & 14 & 13 & 0 & & NT & \\
\hline CBL46 & 12 & 7 & 5 & 0 & 15 & 14 & 14 \\
\hline \multicolumn{2}{|c|}{ Proportion $\geq 10 \%$ specific lysis } & $14 / 20$ & $14 / 20$ & $10 / 20$ & $7 / 13$ & $9 / 13$ & $7 / 13$ \\
\hline \multicolumn{2}{|c|}{ Mean $(\mathrm{SD}) *$} & $21.7(9.2)$ & $15.2(6.9)$ & $13.5(3.1)$ & $15(7)$ & $15(3)$ & $13(5)$ \\
\hline
\end{tabular}

*Infants with specific lysis $\geq 10 \%$. 

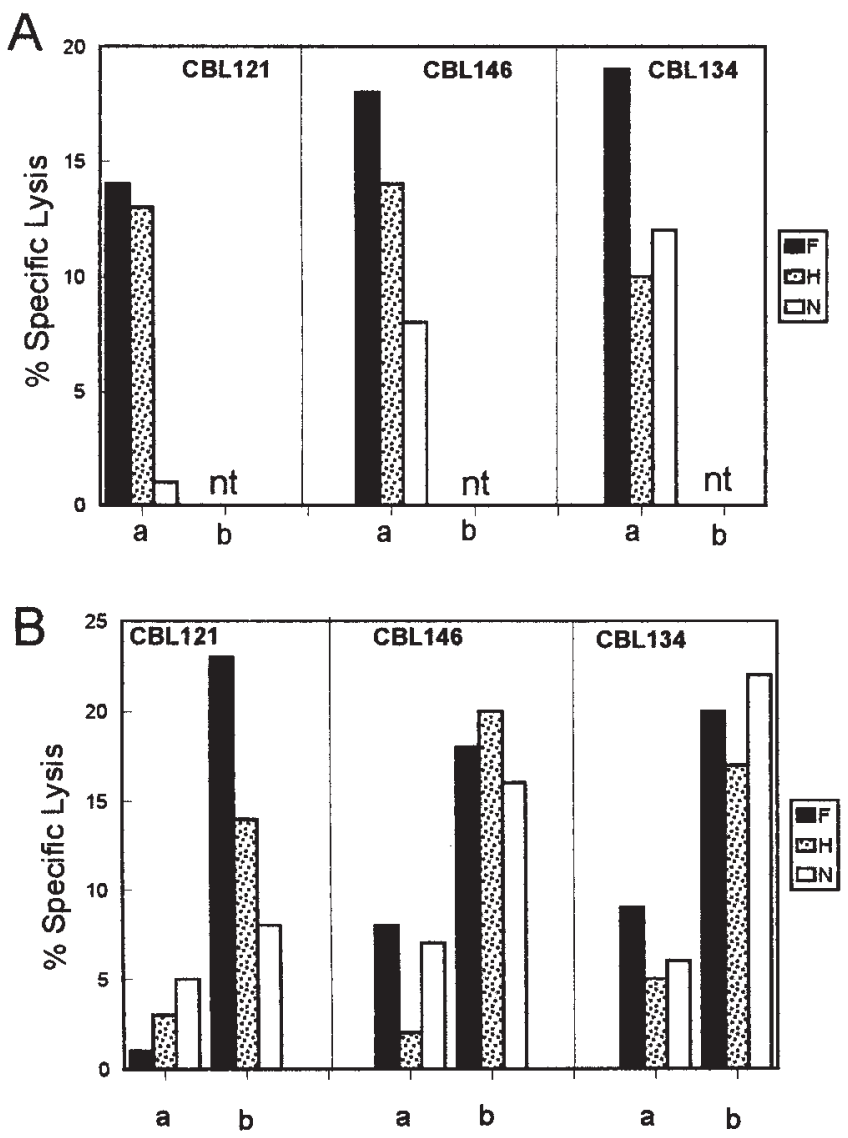

Figure 2. Sequential CTL responses of vaccinees to measles proteins at different time points. PBMC from children vaccinated against measles were tested for direct CTL 4-6 wk after vaccination $(A)$ and 24 wk (CBL 121) and $31 \mathrm{wk}$ (CBL 146, CBL 134) after immunization $(B)$ by direct assay $(a)$ and by stimulation $(b)$. The E/T ratio was 20:1. $n t$, not tested.

donor CBL30 were mediated by $\mathrm{CD}^{+}$cells, whereas only in donor CBL55 could both $\mathrm{CD}^{+}$and $\mathrm{CD}^{+}$killing be demonstrated (Fig. 3).

\section{Discussion}

The Gambia, the first developing country to interrupt measles transmission with a mass campaign (27), continues to encounter measles outbreaks despite a high coverage of $80 \%$ or greater. We present data during recent outbreaks that show a high frequency of CTL responses specific to antigens in the F, $\mathrm{H}$, and $\mathrm{N}$ proteins during the acute stage of measles infection and after recovery. We observed that direct CTL responses were frequent during the acute phase of measles, suggesting a high number of circulating CTL effector cells whereas in vitro stimulation was unsuccessful due to the release of measles virus which abrogated the responses. The finding that CTL activity was of sufficient magnitude to allow detection of measles-specific cytotoxicity using freshly isolated PBMC not requiring in vitro stimulation is unusual and noteworthy. Similar findings, which are also indicative of a high CTL precursor frequency, have been described in $\operatorname{HIV}(28,29)$, in acute EBV infection $(30,31)$, and in patients with HTLV-1 neurological disease (32). The direct CTL responses which were directed

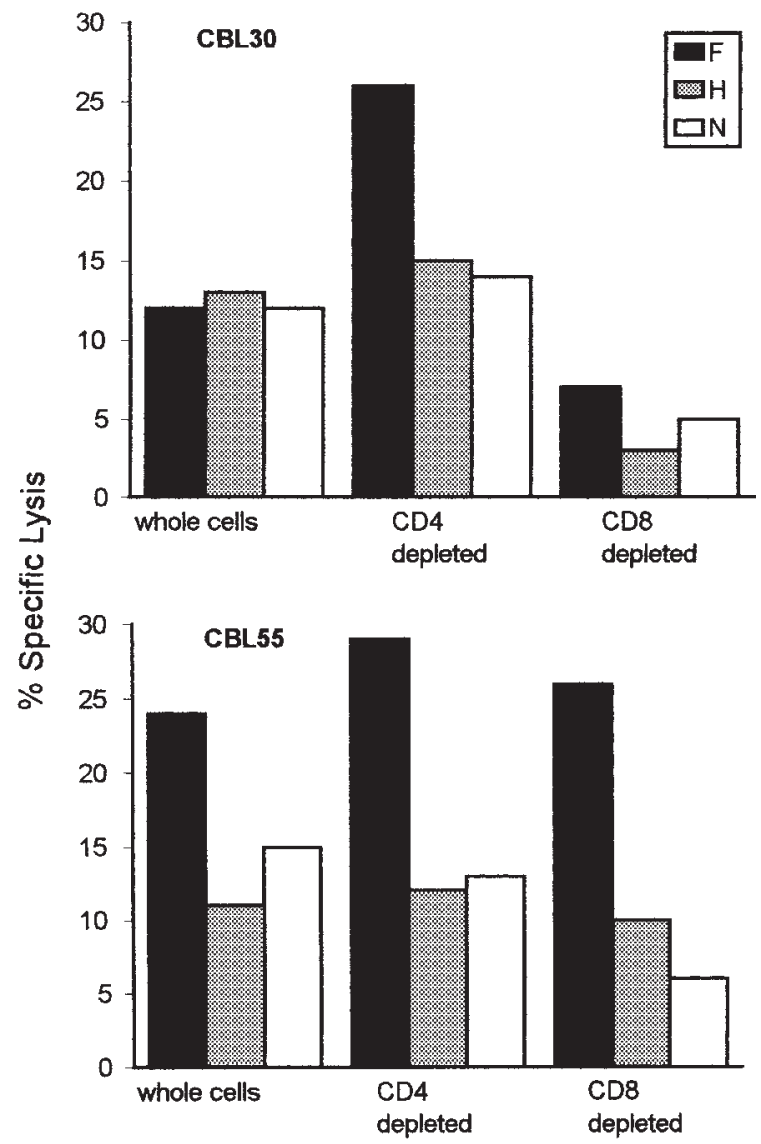

Figure 3. Phenotypic analysis of fresh CTL derived from infants $4 \mathrm{wk}$ after vaccination. PBMC from donor CBL30 and CBL55 were subjected to two rounds of depletion with immunomagnetic beads and then tested against autologous lymphoblastoid cells expressing measles antigens in a direct CTL assay at an E/T ratio of 20:1.

mainly to the $\mathrm{F}$ and $\mathrm{H}$ antigens lend credence to the report from studies in immune adults that these proteins are of importance in protective immunity (22). The presence of direct CTL from most patients, except three who had severe disease, gives further support that cell-mediated immunity plays a role in controlling the virus during infection $(7,9,10)$ as has also been shown in EBV infection $(30,31)$ and in $\operatorname{HIV}(28,29,33)$.

CTL recognize endogenously processed peptides in the context of MHC molecules. After an early controversy about MHC restriction of CTL to measles $(7,34-36)$ it is becoming evident that, although HLA class II-restricted $\mathrm{CD}^{+}{ }^{+} \mathrm{T}$ cells are involved, $\mathrm{MHC}$ class I restriction of $\mathrm{CD}^{+}$phenotype plays a major role in the cellular immunity $(9,22)$. In this study, we were unable to perform HLA class II typing due to time limitations. However, CTL were readily demonstrated when cells were matched at class I loci with allogeneic targets, clearly showing that class I-restricted $\mathrm{CD}^{+} \mathrm{T}$ cells are important in clearance of the virus. Furthermore, the marked cytolysis by $\mathrm{CD}^{+}{ }^{+}$-depleted cells and by $\mathrm{CD}^{+}$cells detached from beads used for this depletion reinforces this concept. However, it is important to note that the CTL responses may not necessarily have been effected solely by $\mathrm{CD}^{+}$class I-restricted cells since cell depletion experiments in one individual also indicated some $\mathrm{CD}^{+}$cell-mediated lysis. Thus, our study was not able 
to show the full extent of the role which the different cell phenotypes and their corresponding MHC restriction play in the overall CTL responses during infection. Since previous reports (20, 34-36) including our recent study of immune adults (22) have shown the involvement of $\mathrm{CD}^{+} \mathrm{T}$ cells in measles cellular cytotoxicity, we must interpret the HLA class I restriction analysis of CTL in our patients with caution. This is particularly true where a negative or poor CTL response was found because we used allogeneic targets, which could imply that optimal HLA matching was not achieved in these assays. However, our results did indicate that $>56 \%$ of subjects respond to two or three polypeptides simultaneously when HLA class I matching is done in the CTL assay and that when targets are completely mismatched at class I and class II loci no lysis occurs.

Confining the analysis to the observed HLA class I-restricted CTL, our data provide a useful indication of the common class I alleles that are involved in CTL to measles in the Gambian population. We found B53, A2, A28 (A68), A1, and B12 (B44 or B45) to be common HLA alleles which may have restricted cytolysis in the study population. Because of limitation in cell numbers, we were unable to perform detailed studies where matching was done at two loci in order to conclude that allele restriction was specific and to dissect the major immunodominant HLA alleles. However, this information allows selection of common HLA alleles in order to map putative peptide epitopes based on known anchor residues for these HLA types $(37,38)$, which would determine the fine specificity of CTL in measles. With accurate molecular HLA typing methods (25), which have been set up recently in our laboratories, we will be able to map CTL epitopes in the target proteins using sequence data obtained from local isolates $(39,40)$. At the moment there are only a few MHC class I measles T cell epitopes that have been identified in humans. These include a nanomer sequence in the F protein found to stimulate an HLA B27restricted CTL clone (20) and recently described HLA 2.1 peptide binding motifs consisting of three epitopes in the $\mathrm{N}$ and one epitope in the $\mathrm{H}$ and polymerase protein, respectively (21). Further analysis of the $\mathrm{F}$ and $\mathrm{H}$ proteins which are highly conserved $(39,40)$ for the presence of class I binding epitopes could be worthwhile, as these may be important components when designing new vaccines.

The rash of measles is a sign of a strong and complicated allergic reaction to the virus in epithelial cells involving immune lymphocytes, antibody, immune complexes, and complement $(41,42)$. Underlying immune deficiency as in leukemia (43) or very severe malnutrition (44) leads to occult and persistent measles without a rash. It was of interest that subjects with severe disease, all of whom had a marked rash, showed lower CTL responses than those with mild or moderate disease. For the above reasons we think these low values are more likely to be due to sequestration or exhaustion of $\mathrm{T}$ cells after a strong immune reaction (45) rather than a primary failure of this arm of the immune response. There was a weak correlation between the level of CTL activity to the F protein and age but this did not hold for the other proteins, which suggests that inadequate CTL responses are not a feature of measles in young children who often have severe measles with a widespread rash. The role that the massive $\mathrm{CD}^{+} \mathrm{CTL}$ response plays in the immunosuppression after measles (46) is unclear. The virus infects dendritic cells in vivo leading to impairment of function of T cells and apoptosis (47) and has also been shown to infect $\mathrm{T}$ cells in vivo (48). Both these types of cells, when activated and infected with measles at the time of the rash, are likely to be killed by CTL with consequent disruption of the immune response. If infection and damage to $\mathrm{T}$ helper type 1 cells predominated, this might lead to loss of cell-mediated immunity and skewing towards a T helper type 2 response (46).

It was evident that after measles infection the majority of individuals established a pool of memory T cells. We were able to show marked measles protein-specific CTL upon restimulation of cells up to $6 \mathrm{mo}$ in the recovery period. It appears that in the recovery period the activated CTL effectors wane and stable memory $\mathrm{T}$ cells specific to the antigens in the glycoprotein and the $\mathrm{N}$ protein develop and are probably crucial for long-term protection in measles. We have shown that in immune adults these memory cells are both $\mathrm{CD}^{+}$and $\mathrm{CD}^{+}$ cells that are HLA class I- and class II-restricted, respectively (22). It is of interest that vaccinated children who contracted measles raised CTL responses similar to those who had not been vaccinated. This fits with the observations that although many cases of measles occur in vaccinees with low antibody levels (49) the disease is usually mild with a very low mortality (12). Vaccine failures which are becoming commonplace in West African countries with high vaccine coverage (12) may be due to a decline in antibody levels, possibly as a result of lack of boosting by wild-type virus rather than a failure of CTL memory. In this context we noted that CTL responses, both direct and stimulated, were similar in vaccinated infants to that found in children and adults after measles. This suggests normal CTL responses despite immunization at an early age. Our results are in agreement with $\mathrm{Wu}(10)$ who demonstrated that the majority of individuals infected with measles despite previous vaccination had a normal capacity to generate CTL to measles.

Immunity to measles in healthy infants is induced currently by live attenuated vaccines. Analysis of CTL responses after vaccination showed that the attenuated vaccine acts similarly to the wild-type virus to induce CTL specific to the F, H, and $\mathrm{N}$ proteins. Our study showed, for the first time, that direct CTL responses could be measured in children after vaccination. As was found in the acute phase of measles direct CTL was stronger and easier to elicit in the first few weeks after vaccination than stimulated CTL. Later, direct CTL waned and restimulation proved more successful. Presumably, soon after vaccination, effector CTL, which are short lived, are in the majority and memory cells are few. In addition, as vaccine strains infect both lymphocytes and monocytes $(41,50)$ stimulation may release virus, which could infect and immunosuppress effector cells. Later virus is absent and restimulation successfully expands clones and oligoclones of memory cells (51).

After vaccination, using autologous B cells as targets, we discerned both $\mathrm{CD}^{+}$and $\mathrm{CD} 4^{+}$mediated direct killing which were presumably restricted through both HLA class I and II antigens, respectively. However, due to restricted cell numbers, we were unable to prove this by mismatching experiments. These responses directed mainly to the $\mathrm{F}$ and $\mathrm{H}$ proteins of the measles virus once more suggested that these antigens were important in providing immunity to measles. These findings may be important because they could also be relevant to the design of other antiviral vaccines such as the nef deleted strains of HIV which are now being proposed (52). For measles, this information allows screening and identification of putative peptide units using overlapping sequences of 
these proteins, which could form the basis of a nonreplicating and safe subunit vaccine that will not cause immunosuppression in infants.

\section{Acknowledgments}

The authors wish to thank Professors A.J. McMichael and A.V.S. Hill (Institute of Molecular Medicine, Oxford, UK) for their support, Dr. $\mathrm{F}$. Wild for the vaccinia recombinant for $\mathrm{F}$ and $\mathrm{H}$ proteins, and the late Dr. Albrecht for the measles virus ED strain. We are grateful to Professor Brian Greenwood, former director of MRC unit in The Gambia, for his invaluable support and advice. We are indebted to our field nurses, Mr. Mansour Nyang and Ms. Awa Kinteh, for their clinical assistance. Finally, we express our gratitude to all the subjects in The Gambia who volunteered for the study.

Financial support for this work was from the National Institutes of Health (grant AI 35174-02/03). A. Jaye was supported by a Training Research Fellowship from The Rockefeller Foundation.

\section{References}

1. Clements, C.J., and F.T. Cutts. 1995. The epidemiology of measles: thirty years of vaccination. Curr. Top. Microbiol. Immunol. 191:13-33.

2. Gellin, B.G., and S.L. Katz. 1994. Measles: state of the art and future directions. J. Infect. Dis. 170(Suppl. 1):S3-S14.

3. Sabin, A.B. 1991. Measles, killer of millions in developing countries: strategy for rapid elimination and continuing control. Eur. J. Epidemiol. 7:1-22.

4. Albrecht, P., F.A. Ennis, E.J. Satzman, and S. Krugman. 1977. Persistence of maternal antibody in infants beyond 12 months: mechanism of measles vaccine failure. J. Pediatr. 91:715-722.

5. Good, R.A., and S.J. Zak. 1956. Disturbance in gammaglobulin synthesis as "experiments of Nature." Pediatrics. 18:109-149.

6. Burnet, F.M. 1968. Measles as an index of immunological function. Lancet. 2:610-663.

7. Kreth, H.W., V. ter Meulen, and G. Eckert. 1979. Demonstration of HLA restricted cells in patients with acute measles. Med. Microbiol. Immunol. 165:203-214.

8. Sissons, J.G.P., D. Colby, W.O. Harrison, and M.B.A. Oldstone. 1985. Cytotoxic lymphocytes generated in vivo with acute measles virus infection. Clin. Immunol. Immunopathol. 34:60-68.

9. van Binnendijk, R.S., M.C.M. Poelen, K.C. Kuijpers, A.D.M.E. Osterhaus, and F.G.C.M. UytdeHaag. 1990. The predominance of $\mathrm{CD}^{+}$T cells after infection with measles virus suggests a role for $\mathrm{CD}^{+}$class I MHC-restricted cytotoxic T lymphocytes (CTL) in recovery from measles. Clonal analyses of human CD8 ${ }^{+}$class I MHC-restricted CTL. J. Immunol. 144:2394-2399.

10. Wu, V.H., H. McFarland, K. Mayo, L. Hanger, D.E. Griffin, and S. Dhib-Jalbut. 1993. Measles virus-specific cellular immunity in patients with vaccine failure. J. Clin. Microbiol. 31:118-122.

11. Aaby, P., J. Butch, I.M. Lisse, A.J. Smits, J. Gomes, M.A. Ferrandes, F. Indi, and M. Soares. 1984. Determinants of measles mortality in a rural area of Guinea-Bissau: crowding, age, malnutrition. J. Trop. Pediatr. 30:164-168.

12. Samb, B., P. Aaby, H. Whittle, A.M. Coll-Seck, and F. Simondon. 1997. Decline in measles case fatality ratio after the introduction of measles immunization in rural Senegal. Am. J. Epidemiol. 145:51-57.

13. de Vries, P., J.P.M. Oosten van-Versteeg, I.K.G. Visser, R.S. van Binnendijk, S.A. Langeveld, A.D.M.E. Osterhaus, and F.G.C.M. Uytdehaag. 1989. Measles virus-specific murine $\mathrm{T}$ cell clones: characterization of fine specificity and function. J. Immunol. 42:2841-2846.

14. Beauverger, P., R. Buckland, and T.F. Wild. 1993. Measles virus antigens induce both type specific and canine distemper virus cross-reactive cytotoxic T lymphocytes in mice: localization of common Ld-restricted nucleoprotein epitope. J. Gen. Virol. 74:2357-2363.

15. Wild, T.F., A. Bernard, D. Spehner, and R. Drillien. 1992. Construction of vaccinia virus recombinants expressing several measles virus proteins and analysis of their efficacy in vaccination of mice. J. Gen. Virol. 73:359-367.

16. Partidos, C.D., and M.W. Steward. 1990. Prediction and identification of a $\mathrm{T}$ cell epitope in the fusion protein of measles virus immunodominant in mice and humans. J. Gen. Virol. 71:2099-2105.

17. Partidos, C.D., C.M. Stanley, and M.W. Steward. 1991. Immune responses in mice following immunization with chimeric synthetic peptides representing B and T cell epitopes of measles virus proteins. J. Gen. Virol. 72:12931299.

18. Partidos, C.D., and M.W. Steward. 1992. The effects of a flanking sequence on the immune response to a B and a $\mathrm{T}$ cell epitope from the fusion protein of measles virus. J. Gen. Virol. 73:1987-1994.

19. van Binnendijk, R.S., C.A. van Baalen, M.C.M. Poelen, P. de Vries, J.
Boes, V. Cerundolo, A.D.M.E. Osterhaus, and F.G.C.M. UydeHaag. 1992. Measles virus transmembrane fusion protein synthesized de novo or presented in ISCOM is endogenously processed for HLA class I and class II-restricted cytotoxic T cell recognition. J. Exp. Med. 176:119-128.

20. van Binnendijk, R.S., J.P.M. Versteeg-van Oosten, M.C.M. Poelen, H.F. Brugghe, P. Hoogerhout, A.D.M.E. Osterhaus, and F.G.C.M. Uytdehaag. 1993 Human HLA class I- and HLA class II-restricted cloned cytotoxic T lymphocytes identify a cluster of epitopes on the measles virus fusion protein. J. Virol. 67:2276-2284.

21. Nanan, R., C. Carstens, and H.W. Kreth. 1995. Demonstration of virusspecific $\mathrm{CD}^{+}$memory $\mathrm{T}$ cells in measles-seropositive individuals by in vitro peptide stimulation. Clin. Exp. Immunol. 102:40-45.

22. Jaye, A., A.F. Magnusen, and H.C. Whittle. 1998. Human leucocyte antigen class I- and class II-restricted cytotoxic T cell responses to measles antigens in immune adults. J. Infect. Dis. 177:1282-1289.

23. Morley, D. 1973. Severe measles in Africa. In Paediatric Priorities in the Developing World. Butterworths, London. 207-230.

24. Terasaki, P.I., D.L. Thrasher, and T.H. Hauber. 1968. Serotyping for hemotransplantation. XIII. Immediate kidney rejection and associated preformed antibodies. In Advances in Transplantation. J. Dauset, J. Hamburger, and G. Mathe, editors. Munksgaard, Copenhagen. 225-229.

25. Bunce, M., C.M. O’Neil, M.C.N.M. Barnado, P. Krausa, M.J. Browning, P.J. Morris, and K.I. Welsh. 1995. Phototyping: comprehensive DNA typing for HLA-A, B, C, DRB1, DRB2, DRB3, DRB4, DRB5, and DQB1 by PCR with 144 primer mixes utilizing sequence specific primers (PCR-SSP). Tissue Antigens. 46:355-367.

26. Crawford, D.H. 1986. Use of the virus to prepare human-derived monoclonal antibodies. In The Epstein-Barr Virus: Recent Advances. M.A. Epstein and B. Achong, editors. Heinemann Medical Books, London. 251-269.

27. de Quadros, C.A., J.M. Olive, B.S. Hersh, M.A. Strasburg, D.A. Henderson, D. Banding-Bennette, and G.A.O. Alleyne. 1996. Measles elimination in the Americas, evolving strategies. J. Am. Med. Assoc. 275:224-229.

28. Gotch, F., S.N. McAdam, C.E.M. Allsopp, A. Gallimore, J. Elvin, M. Kieny, A.V.S. Hill, A.J. McMichael, and H.C. Whittle. 1993. Cytotoxic T cells in HIV2 seropositive Gambians: identification of a virus-specific MHCrestricted peptide epitope. J. Immunol. 151:3361-3369.

29. Gotch, F.M., D.F. Nixon, N. Alp, A.J. McMichael, and L.K. Borysiewicz. 1990. High frequency of memory and effector gag specific cytotoxic T lymphocytes in HIV seropositive individuals. Int. Immunol. 2:707-712.

30. Callan, M.F.C., N. Steven, P. Krausa, J.D.K. Wilson, P.A.H. Moss, G.M Gillespie, J.I. Bell, A.L. Rickinson, and A.J. McMichael. 1996. Large clonal expansions of $\mathrm{CD}^{+} \mathrm{T}$ cells in acute infectious mononucleosis. Nat. Med. 2:906911.

31. Tomkinson, B.E., D.K. Wagner, D.L. Nelson, and J.L. Sullivan. 1987. Activated lymphocytes during acute Epstein-Barr virus infection. J. Immunol. 139:3802-3807.

32. Jacobson, S., H. Shida, D.E. McFarlin, A.S. Fauci, and S. Koenig. 1990 Circulating $\mathrm{CD}^{+}$cytotoxic $\mathrm{T}$ lymphocytes specific for HTLV-1 px in patient with HTLV-1 associated neurological disease. Nature. 348:245-248.

33. Walker, B.D., S. Chakrabarti, B. Moss, T.J. Paradis, T. Flynn, A.G. Durno, R.S. Blumberg, J.C. Kaplan, M.S. Hirsch, and R.T. Schooley. 1987. HIV-specific cytotoxic T lymphocytes in seropositive individuals. Nature. 328: 345-348.

34. Lucas, C.J., W.E. Biddison, D.L. Nelson, and S. Shaw. 1982. Killing of measles virus-infected cells by human cytotoxic T cells. Infect. Immun. 38:226232.

35. Jacobson, S., J.R. Richert, W.E. Biddison, A. Satinsky, R.J. Hartzman, and H.F. McFarland. 1984. Measles virus-specific $\mathrm{T}^{+}{ }^{+}$human cytotoxic $\mathrm{T}$ cell clones are restricted by class II HLA antigens. J. Immun. 133:754-757.

36. Richert, J.R., H.F. McFarland, D.E. McFarlin, A.H. Johnson, J.H. Woody, and R.J. Hartzman. 1985. Measles-specific T cell clones derived from a twin with multiple sclerosis: genetic restriction studies. J. Immunol. 34:15611566 .

37. Falk, K., O. Rotzchke, S. Stevanovic, G. Jung, and H.G. Rammensee. 1991. Allele-specific motifs revealed by sequencing of self-peptides eluted from MHC molecules. Nature. 351:290-296.

38. Elliot, T., P. Driscoll, M. Smith, and A.J. McMichael. 1994. Peptide epitope selection by class I MHC molecules. Curr. Biol. 3:854-866.

39. Outlaw, M.C., A. Jaye, H.C. Whittle, and C.R. Pringle. 1997. Clustering of haemagglutinin gene sequences of measles viruses isolated in the Gambia. Virus Res. 48:125-131.

40. Rota, J.S., K.B. Hummel, P.A. Rota, and W.J. Bellini. 1992. Genetic variability of the glycoprotein genes of current wild type measles isolates. Virology. 188:135-142.

41. Whittle, H.C., and P. Aaby. 1996. Measles. In Oxford Textbook of Medicine. D.J. Weatherall, J.G.G. Lodingham, and D.A. Warrell, editors. Oxford University Press, Oxford. 375-381.

42. Kimura, A., K. Tosaka, and T. Nakao. 1975. Measles rash. I. Light and electron microscopic examination of skin eruptions. Arch. Virol. 47:295-307.

43. Enders, J.F., K. McCarthy, A. Mitus, and W.J. Cheatham. 1959. Isolation of measles virus at autopsy in cases of giant cell pneumonia without rash. N. Engl. J. Med. 261:875-881. 
44. Smythe, P.M., G.G. Breton-Stiles, H.J. Grace, A. Mafoyane, M. Schonland, H.M. Coovadia, W.E.K. Loening, M.A. Parent, and G.H. Vos. 1971. Thymolymphatic deficiency and depression of cell mediated immunity in proteincalorie malnutrition. Lancet. 11:939-944.

45. Whittle, H.C., J. Mee, A. Werblinstice, A. Yakubu, C. Omiora, and N. Gomwalk. 1980. Immunity to measles in malnourished children. Clin. Exp. Immunol. 42:144-151.

46. Griffin, D.E., B.J. Ward, and L.M. Esolen. 1994. Pathogenesis of measles virus infection: an hypothesis for altered immune responses. J. Infect. Dis. 170(Suppl.):S24-S31.

47. Fugier-Vivier, I., C. Servet-Delprat, P. Rivailler, M.C. Rissoam, J. Liuy, and C. Rabourdin-Combe. 1997. Measles virus suppresses cell-mediated immunity by interfering with the survival and functions of dendritic and T cells. $J$. Exp. Med. 186:813-823.

48. Whittle, H.C., J. Dossetor, A. Oduloja, A.D.M. Bryceson, and B.M. Greenwood. 1978. Cell mediated immunity during natural measles infection. $J$.
Clin. Invest. 62:678-684.

49. Samb, B., P. Aaby, H.C. Whittle, A.M. Coll Seck, S. Rahman, J. Bennett, L. Markowitz, and F. Simondon. 1995. Serologic status and measles attack rates among vaccinated and unvaccinated children in rural Senegal. Pediatr. In fect. Dis. J. 14:203-209.

50. Joseph, B.S., P.W. Lampert, and M.B.A. Oldstone. 1975. Replication and persistence of measles virus in defined subpopulations of human leukocytes. J. Virol. 16:1638-1649.

51. Auwaerter, P.G., G.D. Hussey, E.A. Goddard, J. Hughes, J.J. Ryon, P.M. Strebel, D. Beatty, and D.E. Griffin. 1996. Changes within T cell receptor $\mathrm{V} \beta$ subsets in infants following measles vaccination. Clin. Immunol. Immunopathol. 79:163-170.

52. Johnson, R.P., R.L. Glickman, J.Q. Yank, A. Kaur, J.T. Dion, M.J. Mulligan, and R.C. Desrosiers. 1997. Induction of vigorous cytotoxic T-lymphocyte responses by live attenuated Simian immunodeficiency virus. J. Virol. 71:77117718 